\title{
Semen Banking and Cryobiology
}

\author{
Pankaj Talwar \\ Head, Assisted Reproductive Technologies Center, Army Hospital (Research and Referral), New Delhi, India \\ Trained in Human Embryonic Stem Cell Biology (Israel) and Onco-ART (France)
}

Correspondence: Pankaj Talwar, Head, Assisted Reproductive Technologies Center, 35-Bank Enclave, Rajouri Garden New Delhi-110027, India, e-mail: pankaj_1310@yahoo.co.in

\section{ABSTRACT}

Cryo banking of spermatozoa is an essential aspect of fertility preservation. With the advancements in cryobiology and better understanding of cryoprotectants and assisted reproduction, indications for semen banking are expanding. The exponential developments that have occurred over the years in the field of cryopreservation have proved that frozen sperm is as good as fresh sperm in fertilizing oocytes. Semen banking has major role in fertility preservation in cancer patients.

Keywords: Cryobiology, Assisted reproduction, Cryopreservation, Cryoprotectant.

\section{INTRODUCTION}

Desire to leave genetic footprints in this world has been a long cherished dream of mankind. The concept of sperm banking has fulfilled these dreams partly, by being able to preserve gametes and genital tissues.

The banking of the male gametes involves initial exposure of the spermatozoa to the cryoprotectant and gradually cooling them to subzero temperatures as per desired cooling curve. ${ }^{1}$ Semen sample in suitable container is then cryopreserved in liquid nitrogen at 1960 centigrade till required. When required cryobioreposited semen sample is then thawed, gradually warmed to the room temperature and diluted with suitable buffered media. Cryoprotectant is washed away and the thawed sample evaluated and used for insemination, intracytoplasmic sperm injection or for research purposes.

The male gamete must maintain its macro and micro architectural structure along with genomic integrity during the whole procedure and recover its physiological functions completely after the procedure. ${ }^{2}$

Factors known to effect outcome of this delicate procedure depends upon the quality of the semen specimen, developmental stage at which sperms are being frozen, type of cryoprotectant being used and the freezing protocols. ${ }^{3}$

\section{BACKGROUND OF SPERM BANKING}

Freezing and thawing techniques have been used to cryopreserve semen since $1776 .{ }^{4}$ Advancements in the equipments, disposables and awareness about sterility have also helped the cryobiologist and embryologist to further enhance the freeze thaw cycle results. This approach of

Date of Received: 31-01-11

Date of Acceptance: 30-04-11

Date of Publication: May 2011 cryopreserving human semen has become an acceptable procedure in assisted reproductive technology (ART) laboratories across the world.

Few of the developmental milestones are worth mentioning:

- 1776-Observations by Spallanzani on the effects of freezing on human sperm and subsequent recovery of motility on warming.

- 1866-Montegazza proposed semen banking for veterinary practice and for soldiers going to battle field. ${ }^{5}$

- $\quad 1930$ - Shettels and Jahnel S observed that sperm survives at temperatures as low as $269^{\circ} \mathrm{C}$. 6,7

- 1949-Polge, Smith and Parkes-accidental discovery of cryoprotective properties of glycerol. ${ }^{8}$

- 1963-Sherman reported birth of 1st child born after insemination by sperms which had been frozen by using liquid nitrogen. ${ }^{9}$

\section{PRINCIPLES OF CRYOBIOLOGY}

Cryopreservation is a process which maintains cellular life for an extended period of time at subzero temperatures. The aim of any cryopreservation protocol is to minimize cell membrane damage associated with exposure to low temperatures, regulate cell volume during the procedure and prevent lethal intracellular ice crystal formation. This can be achieved by controlling intracellular and extracellular movement of solutes and water. ${ }^{10}$

The outcome of freeze thaw cycle depends on various factors:

1. The cryoprotectant (extender) in which the cells are suspended during cooling and warming

2. The rate at which the cells are cooled

3. The temperature at which the sample is plunged into liquid nitrogen

4. The warming rate

5. Cryoprotectant removal after thawing.

At least half of the motile sperm will sustain cryoinjury when subjected to cryopreservation and thawing. ${ }^{11}$ 
The typical effects observed in frozen-thawed spermatozoa derive from the unique nature of the cell. Human spermatozoa are relatively simple cells with a large surface area/volume ratio and have high permeability to water. This ensures rapid osmotic equilibrium in the presence of cryoprotectants. The genetic material is highly condensed and is less prone to injury by cryoprotectants unlike embryos.

Cell membranes of all mammalian species are composed of a phospholipid bilayer and associated membrane proteins (receptors, enzymes, etc). Phospholipid bilayers are composed of a polar head group with hydrocarbon tails. Specific phospholipids polar heads face outward and others face inward with hydrocarbon tails directed inward from each polar head group. ${ }^{12}$

Cold shock etiology involves damage to the cellular membranes and alteration in metabolic function, probably caused by changes in the arrangement of membrane constituents. When a cell membrane is cooled, a reordering of the membrane components occur which leads to increased membrane viscosity and decreased fluidity. A decrease in temperature causes a thermotropic phase transition in the membrane phospholipids from a liquid-crystalline to a gel phase, resulting in more rigid membrane structure. The occurrence of cold shock can be prevented by controlling the rate of cooling and by adding protective compounds to semen diluents. ${ }^{13-15}$

\section{Changes in Volume of Sperm When Exposed to Cryoprotectants}

Spermatozoa undergo several volume changes as they undergo cryopreservation and thawing. The sperms undergo rapid shrinkage as intracellular water leaves the cell in response to the hyperosmotic extracellular solution. Gradually, the sperms return to its original volume as the cryoprotective agent (CPA) permeates the cell. The CPA's presence in the intracellular and extracellular water lowers the freezing point of the cell and the solutes, allowing them to remain in super cooled state.

Ice formation is initiated in the extracellular medium. As more water leaves the cryopreservation medium to contribute to crystal formation, the concentration of particles in the remaining liquid increases, resulting in a continuous drop in the freezing point of the remaining liquid and an increase in extracellular osmotic pressure. With rising hyperosmolarity of the extracellular fluid more intracellular water is drawn out of the spermatozoa leaving the cell dehydrated and reducing the risk of lethal intracellular ice formation. ${ }^{16}$

\section{INDICATIONS OF SEMEN CRYOPRESERVATION}

Sperm banking is the process of semen cryopreservation using well-documented protocols for the use of the same at a later date. Semen can be preserved for the use by the individual himself. ${ }^{17}$ The sample can be used by him at a later date and is termed as autologous sperm banking or client depositor semen cryofreezing. ${ }^{18}$ It can be also banked from fertile donors after screening for the purpose of third party reproduction Table 1. Adequate care is taken to do phenotypic and blood group matching in these cases. Matching physical characteristics and race of the partner, hair color, texture and eye color are mandatory. The indications of semen banking are ever increasing in this modern era. The common indications are enumerated in Table 2.

\section{OUTLINE OF CRYOPROTECTANTS}

\section{Biochemical and Physical Aspects of Sperm Cryopreservation}

Sperms subjected to cryopreservation and thawing have reduced viability, motility and fecundity. Morphological damage to the membranes and acrosome is well documented. ${ }^{19}$ Loss of the superoxide dismutase enzyme from the plasma membranes, ${ }^{20}$ loss of acrosomal integrity and increased plasma membrane permeability are just a few of the cell altering or damaging events which are associated with cryopreservation and thawing.

All the cryopreservation protocols are based on the theory that cell membrane damage can be minimized through addition of suitable cryoprotective agents, buffer agents, controlling the osmolality and $\mathrm{pH}$ of cryopreservation medium and controlling the freezing rate during the procedure. ${ }^{21}$

A variety of extenders (cryoprotective media) exist for the cooling and cryopreservation of semen (Table 3). The purpose of the extender is manifold. The media contain nutrient, a buffer, a cryoprotectant agent and antibiotic. A typical nutrient added is a sugar, such as glucose or sucrose, which serves to provide

Table 1: Terminologies used in semen banking

\begin{tabular}{ll}
\hline Terminologies & Description \\
\hline Cryopreservation & $\begin{array}{l}\text { The sub-branch of cryobiology that deals with the reversible suspension of life in the frozen state at subzero } \\
\text { temperatures using cryoprotectants } \\
\text { Temporary storage/isolation of semen in a separate cryocans till the donor is proved negative for the } \\
\text { communicable disease agent }\end{array}$ \\
A facility that collects, freezes, stores and distributes semen sample \\
Client depositor & $\begin{array}{l}\text { Patient who cryopreserved his semen for insemination of a partner at latter date } \\
\text { One who provides his own semen for cryobanking for artificial insemination of a recipient other than }\end{array}$ \\
his wife or partner & A sperm donor who may know the recipient and directs the laboratory to freeze his semen for use by \\
specific individuals who are not his partner & A semen donor whose identity is not revealed to the recipient
\end{tabular}


energy source for the sperm. Buffers are added to balance $\mathrm{pH}$ and osmolarity of the solution. An ideal biological buffer should have a $\mathrm{pH}$ value between 6 and $8{ }^{22}$ The role of the buffer in cryopreservation is to pick-up hydrogen ions in the surrounding media, thereby assisting in dehydration of the cell and maintaining a neutral $\mathrm{pH}$.

\section{Basics of Cryoprotectants as applied to Semen Banking}

Cryoprotectants have been divided into two classes. Glycerol has remained the cryoprotectant of choice for preservation of spermatozoa for most species. ${ }^{23}$ Glycerol is superior to dimethylsulfoxide (DMSO) or ethylene glycol as a cryoprotectant. ${ }^{24}$ The protective effects of glycerol are mediated by its colligative properties, depression of freezing point, alteration of cell membrane properties by inducing changes in lipid packing structure and the consequent lowering of electrolyte concentrations in the unfrozen fraction at any given temperature, which will help to counter the harmful 'solution effects' imposed during the freezing process. ${ }^{25}$ In order to improve cryosurvival rates, more complex diluents containing other mainly non-permeable cryoprotective agents, such as glycine, zwitterions, citrate and eggyolk were developed. ${ }^{26}$ Among the earliest and best known extenders for human semen is glycerol egg-yolk citrate (GEYC). Lipoproteins and phospholipid fractions of egg yolk were originally added to cryopreservation media in an effort to protect the sperm from the deleterious effects of cold shock by protecting the integrity of the plasma membrane. Studies have demonstrated the binding of various lipid constituents of egg yolk to the spermatozoa membrane. ${ }^{27}$ Commonly used human sperm preserving medium (HPSM) is a modified Tyrode's medium containing glycerol (5-7.5\% v/v final volume), sucrose, glucose and glycine as cryoprotective agents, human serum albumin as stabilizing agent and HEPES [(N-(2-hydroxyethyl)-piperazine-N'-(2-ethanesulfonic acid)] as the buffering agent. Other commonly used cryoprotective buffer is a zwitterions buffer system containing TES (N-tris-(hydromethyl)-methyl-2-aminoethane sulfonic

Table 2: Current approaches to semen banking

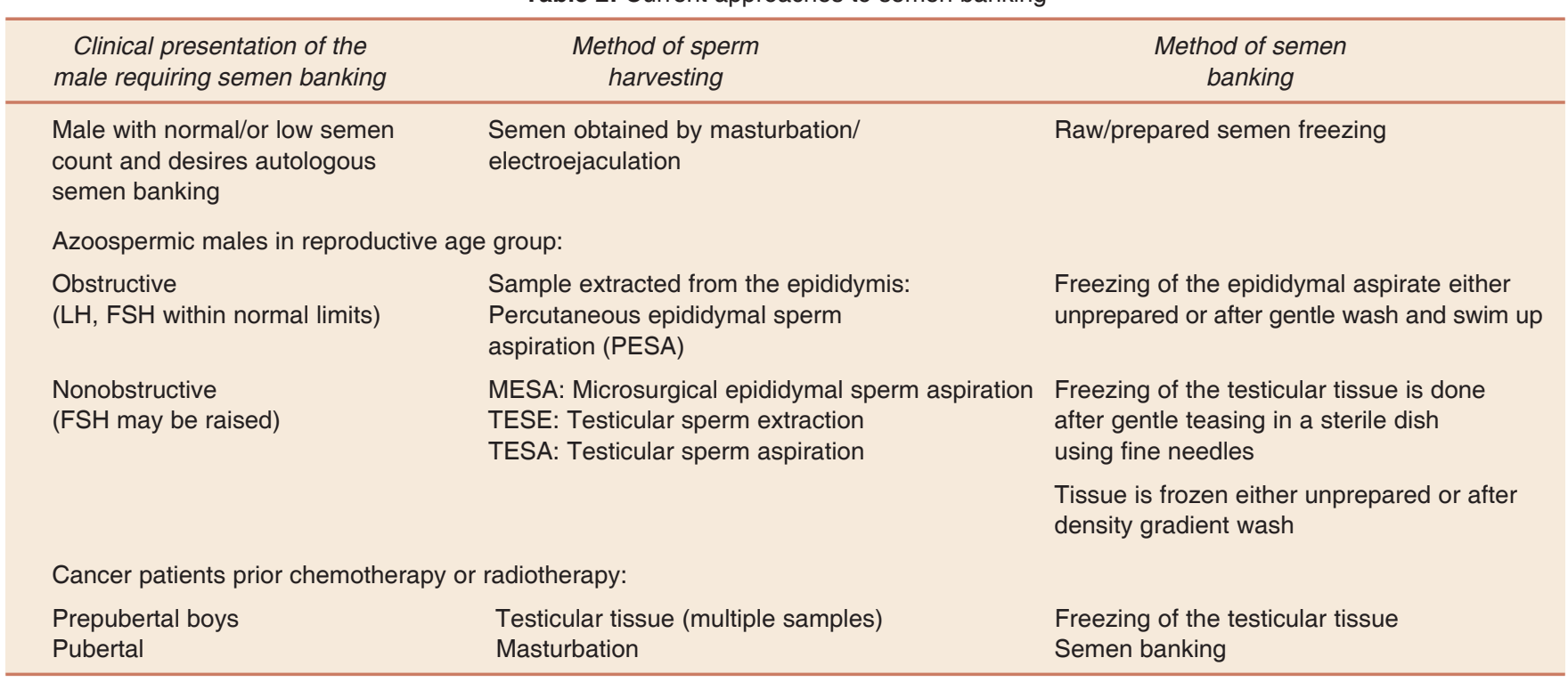

Table 3: Types of cryoprotectants

\begin{tabular}{lll}
\hline \multicolumn{1}{c}{ Mechanism of action } & \multicolumn{1}{c}{ Names } \\
\hline Permeating & $\begin{array}{l}\text { Permeating cryoprotectants are compounds that readily } \\
\text { permeate the plasma membranes of cells } \\
\text { Their movements across the membranes follow the } \\
\text { osmolarity gradient } \\
\text { These molecules form hydrogen bonds with } \\
\text { water molecules and prevent ice crystallization }\end{array}$ & $\begin{array}{l}\text { Dimethyl sulfoxide (DMSO), propylene glycol } \\
\text { glycerol } \\
\text { Glycerol is commonly used for semen freezing }\end{array}$ \\
& $\begin{array}{l}\text { Nonpermeating cryoprotectants are large molecules } \\
\text { that remain extracellular }\end{array}$ & Sucrose, raffinose and glycine \\
& $\begin{array}{l}\text { These create osmolarity gradient by drawing water from } \\
\text { within the cell, thus dehydrating the intracellular space } \\
\text { Can be toxic to the cells at higher temperatures and } \\
\text { after prolonged exposure } \\
\text { Used in combination with the permeating cryoprotectants } \\
\text { to prevent cytotoxicity }\end{array}$ & \\
\hline
\end{tabular}


acid) TRIS (tris-(hydroxymethyl)-aminomethane). This TESTRIS combination (usually abbreviated to 'TEST') is most often used in conjunction with eggyolk and citrate with glycerol as the permeating cryoprotectant. In the initial report, it proved superior to glycerol alone as a cryoprotectant. This remarkable result was largely due to the very rapid freezing protocol employed, and was impossible to duplicate using standard cooling methods. ${ }^{28}$

The addition of the cryoprotectant glycerol has been shown to increase the motile sperm cryosurvival to an average of $50 \%$ well above the $<20 \%$ cryosurvival reported without addition of glycerol. The cryoprotectant DMSO was shown to be unsuitable for sperm cryopreservation as it had lower postthaw percent motility when compared to glycerol. Numerous studies have reported irreversible reduction in sperm motility after exposure to glycerol and other intracellular CPAs. ${ }^{29}$

\section{ESSENTIALS OF FREEZE-THAW CYCLE}

\section{Decision of Semen Packaging Protocol before the Procedure and its Importance to the Reproductive Biologist}

Semen parameters should be thoroughly assessed using WHO criteria. We should decide the outcome of the procedure which will further guide the freezing protocol. If the sample is satisfactory with good count and motility, we may freeze raw sample with aim to carry out IUI at later date. On the other hand, an oligospermic sample with round cells and debris should be prepared and packaged for ICSI. Finally, the methodology depends upon the experience of the reproductive biologist and the laboratory protocols.

\section{Specimen Glycerolization}

Glycerol is added directly or indirectly as a component of a cryopreservation medium to neat semen/prepared semen (swim up) in drop by drop fashion slowly over a period of 2 to 3 minutes with continuous mixing of both. This step is essential to reduce toxicity of the cryoprotectant as it can cause sudden osmotic shock to the sperms. The glycerol is metabolized during the procedure with formation of neutral lipid. It is suggested that the metabolized glycerol may contribute to the plasma membrane of the sperm increasing its stability which may lead to improved post-thaw motility (Table 4). ${ }^{30}$

\section{Packaging of Semen after Addition of Cryopreservative}

Glycerated or extended semen can be cryopreserved in various containers. Factors, which influence the decisions, include the

Table 4: Guidelines for better recovery

\begin{tabular}{|c|c|c|}
\hline & Preventive strategies & Guidelines \\
\hline \multirow[t]{2}{*}{1} & Freezing initiation & $\begin{array}{l}\text { To avoid cytotoxic effects (reactive oxygen species) release from immotile/dead spermatozoa, it is } \\
\text { suggested that the semen sample is prepared and frozen soon after collection }\end{array}$ \\
\hline & & Raw sample may also be banked but immediately after liquefaction \\
\hline 2 & Accidental thawing & $\begin{array}{l}\text { The sperm's plasma membrane is very sensitive. Careless handling of the frozen semen straw will } \\
\text { injure the spermatozoal plasma and acrosomal membranes resulting in a low sperm survival rate after } \\
\text { thawing }\end{array}$ \\
\hline 3 & $\begin{array}{l}\text { Cryoprotectant removal } \\
\text { after thawing }\end{array}$ & $\begin{array}{l}\text { Glycerol as a cryoprotectant is toxic for sperms if exposed for long period at room or higher temperatures } \\
\text { Thus post-thaw survival should quickly be assessed and the sperm sample washed to remove all } \\
\text { traces of glycerol }\end{array}$ \\
\hline
\end{tabular}

Table 5: Packaging of the semen sample

\begin{tabular}{|c|c|c|c|}
\hline & & Advantages & Disadvantages \\
\hline Straws & $\begin{array}{l}\text { Ionomeric resin CBS } \\
\text { High security } \\
\text { (Cryo Biosystem, } \\
\text { Paris, France) }\end{array}$ & $\begin{array}{l}\text { Straws are available in a } \\
\text { variety of colors suitable for } \\
\text { the easy identification of samples, } \\
\text { and many hundreds can be stored } \\
\text { in plastic goblets in canisters within } \\
\text { liquid nitrogen containers }\end{array}$ & $\begin{array}{l}\text { 1. Maximum capacity of approximately } 0.5 \mathrm{ml} \text { only } \\
\text { 2. Overfilled straws are prone to cracking and expelling the } \\
\text { powder sealing plugs into the liquid nitrogen } \\
\text { 3. Labeling and filling difficulties } \\
\text { 4. A high surface/volume ratio which makes the sample } \\
\text { very susceptible to warming shock damage resulting } \\
\text { from exposure to ambient temperatures during handling }\end{array}$ \\
\hline Cryovials & $\begin{array}{l}\text { Polypropylene with } \\
\text { screw caps }\end{array}$ & $\begin{array}{l}\text { These are easy to fill and stores } \\
\text { nearly } 1.5 \mathrm{ml} \text { of the semen plus } \\
\text { cryoprotectant mixture }\end{array}$ & $\begin{array}{l}\text { 1. Storage on aluminum canes is not dependable as they } \\
\text { lose their memory and cryovials may jump off the holder } \\
\text { 2. Screw-top vials do not maintain their seals. They have } \\
\text { the potential of exploding upon thawing because liquid } \\
\text { nitrogen trapped in the vials expand to many times its } \\
\text { volume when it converts to gaseous nitrogen } \\
\text { 3. The low surface: volume ratio and thick wall of the } \\
\text { cryovial increase the time required for samples to reach } \\
\text { critical temperatures, and thus increase the risk of } \\
\text { damage from brief exposure to ambient temperatures }\end{array}$ \\
\hline $\begin{array}{l}\text { Glass } \\
\text { vials }\end{array}$ & Glass & $\begin{array}{l}\text { None over the other available } \\
\text { cryocontainers }\end{array}$ & $\begin{array}{l}\text { Glass vials are very fragile, thus there use is } \\
\text { discouraged }\end{array}$ \\
\hline
\end{tabular}


volume of sample to be cryopreserved, ease of container labeling, handling, storage and recovery as well as biocompatibility of the packaging material (Table 5).

\section{Cooling and Warming Rates}

The outcome of sperm cryosurvival is related to the rate at which the cells are cooled and warmed (Table 6). ${ }^{31}$

\section{Freezing}

Sperm cryopreservation is accomplished by using liquid nitrogen vapors for noncontrolled rate or a programmable freezer for controlled rate cooling (Figs 1 and 2). Regardless of the cooling process, the ultimate quality control appraisal of sperm cryopreservation is the cryosurvival of the spermatozoa determined during thawing (Tables 7 and 8). ${ }^{32}$

\section{Storage}

Once specimens attain temperature of $-80^{\circ} \mathrm{C}$ to $-120^{\circ} \mathrm{C}$, they are immediately plunged into liquid nitrogen. After plunging, the vials are quickly transferred to a precooled, labeled aluminum cane/goblet for storage in liquid phase of liquid nitrogen tank. When freezing semen by noncontrolled rate protocol, vials may be loaded onto the aluminum cane prior to cryopreservation to eliminate the need for transfer after cryopreservation. Every effort should be made to limit the time; specimens spend out of the liquid phase of liquid nitrogen (Fig. 3).
Straws are quickly transferred to precooled, labeled plastic goblets, snapped onto a labeled aluminum cane. Straws should be oriented in the goblet so that identifying information can be read without completely withdrawing the straw from the goblet. Aluminum canes are placed in predetermined locations within the cryostorage vessel. All storage containers should be stored in a secured room in locked/chained containers. Liquid nitrogen dewars and storage tanks are available in a variety of sizes. Dewars require manual filling while most storage tanks have an automatic filling feature. Liquid nitrogen levels in storage units should be monitored regularly at all times. It is important to appreciate the length of time cryopreserved sperm may be stored for. At $-196^{\circ} \mathrm{C}$, storage of sperms, even for a lengthy period of time, does not affect the survival rates. Liquid nitrogen holds specimens at a temperature $\left(-196^{\circ} \mathrm{C}\right)$ at which there is virtually no movement of atoms or molecules. At temperatures above $-130^{\circ} \mathrm{C}$, atoms and molecules are able to move. Temperatures of $-90^{\circ} \mathrm{C}$ and above allow ice crystal growth and even short periods of exposure to such temperatures can cause lethal damage to cells. As long as the cells are maintained at $-196^{\circ} \mathrm{C}$, the only known potential for cell damage is degradation of deoxyribonucleic acid (DNA) caused by background radiation.

Based on normal background radiation of 0.1 rads/year, it has been predicted that the male gametes should maintain its genetic integrity for over 200 years when stored at $-196^{\circ} \mathrm{C}$.

Table 6: Principles of cryopreservation

\begin{tabular}{|c|c|c|}
\hline Avoid & Phase of freeze-thaw cycle & Principle \\
\hline \multirow[t]{3}{*}{ Ice-crystal formation } & $\begin{array}{l}\text { When water is cooled to below its freezing point, it solidifies in a } \\
\text { crystalline structure known as ice }\end{array}$ & $\begin{array}{l}\text { Ice-crystal formation can damage the } \\
\text { cytoplasmic organelles and plasma } \\
\text { membranes of the cells }\end{array}$ \\
\hline & $\begin{array}{l}\text { Because ice is less dense than liquid water, it necessarily follows } \\
\text { that ice crystals occupy a greater volume than does the } \\
\text { liquid water from which they were formed }\end{array}$ & $\begin{array}{l}\text { It should be avoided for } \\
\text { successful cryopreservation }\end{array}$ \\
\hline & $\begin{array}{l}\text { As adjacent volumes of liquid water within a cell solidify, } \\
\text { their expansion into ice causes pressure and shearing forces on } \\
\text { intracellular organelles, which can suffer considerable damage }\end{array}$ & \\
\hline \multirow[t]{3}{*}{ Osmotic shock } & $\begin{array}{l}\text { As water transitions from liquid to ice, any solutes in the } \\
\text { liquid phase are excluded from the solid component }\end{array}$ & $\begin{array}{l}\text { Osmotic shock should be avoided at } \\
\text { every step of semen freezing }\end{array}$ \\
\hline & This lowers the freezing point of the remaining unfrozen solution & $\begin{array}{l}\text { Disturbance of the osmolarity gradient } \\
\text { may damage the cell and release } \\
\text { reactive oxygen species }\end{array}$ \\
\hline & $\begin{array}{l}\text { As the temperature drops and the solid form proliferates, } \\
\text { the concentration of electrolytes and other solutes can } \\
\text { reach very high levels }\end{array}$ & \\
\hline \multirow[t]{3}{*}{$\begin{array}{l}\text { Recrystallization and } \\
\text { solution effects }\end{array}$} & $\begin{array}{l}\text { During rewarming, the solid ice melts and releases free water, } \\
\text { resulting in decreasing osmolarity of the surrounding solution }\end{array}$ & $\begin{array}{l}\text { Rewarming may be slow or rapid } \\
\text { depending upon the freezing curve }\end{array}$ \\
\hline & $\begin{array}{l}\text { With slow rewarming, there is possibility of water molecules } \\
\text { thawing and recrystallizing. These ice crystals may damage the cells }\end{array}$ & \\
\hline & $\begin{array}{l}\text { With rapid rewarming rate, sudden reduction in extracellular } \\
\text { osmolarity may lead to rapid shifts of free water across and } \\
\text { into the cells } \\
\text { This can cause cellular damage by cellular swelling and } \\
\text { sudden osmotic changes }\end{array}$ & \\
\hline
\end{tabular}




\section{Thawing}

Practical approach to semen thawing would be to wash the vials/ straws in running water. They should be cleaned externally till the sweating disappears over a period of few minutes (Fig. 4). Once the sample is thawed, mix the sample well with a pipette before sampling. Perform the sperm count and assess the motility as per WHO guidelines. Specimen should be processed immediately after post-thaw analysis.

\section{EFFECTS OF CRYOFREEZE/THAW CYCLE}

The success of cryopreservation is measured by the number of motile spermatozoa recovered post-thaw. There is nearly 30 to $40 \%$ loss in motility in the thawed sample. ${ }^{33}$ Studies have compared the recovery of post-thaw motility obtained with the various cryoprotective extenders and some of their derivatives. Results are conflicting with no obviously superior candidate emerging, but this is probably a reflection of the various cooling and thawing rates employed by the different research groups, making comparison difficult. It is recommended that additional tests of functional/fertilization ability of the sperms, such as

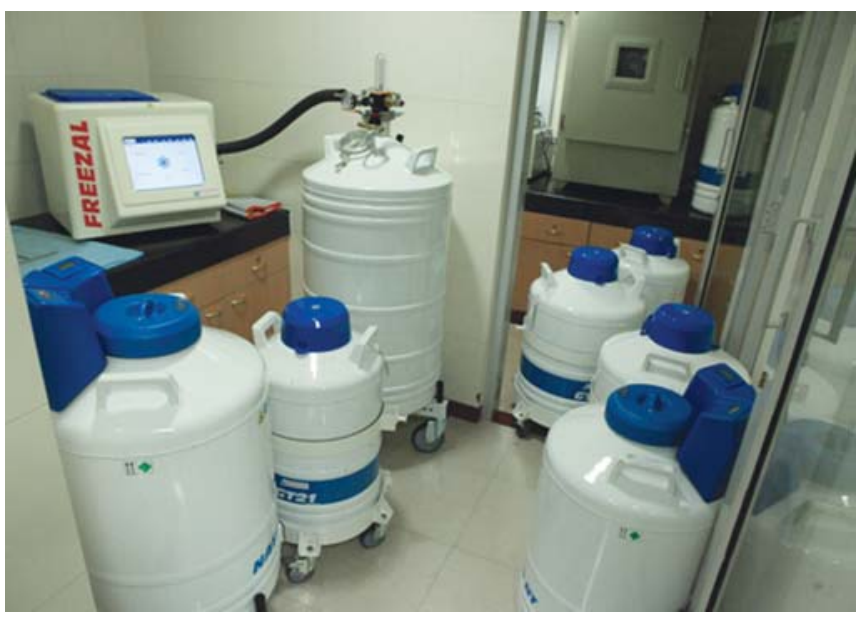

Fig. 1: Cryobiology laboratory freezal cryofreezer and cryocans of various sizes



Fig. 2: Typical freezing curve for semen freezing as seen on the freezal cervical mucus penetration or zona-free hamster oocyte fusion testing, are applied to assess the potential fertility of cryopreserved spermatozoa. ${ }^{34}$

\section{LEGISLATION PERTAINING TO THE SEMEN BANKING}

Indian Council of Medical Research has issued comprehensive guidelines for assisted reproductive technology centers. These are guidelines which may be applied to any functioning semen bank. An ART clinic or a law firm or any other suitable independent organization may set up a semen bank. All donors should produce their semen samples within the collection area of the center so, that the sample cannot be substituted by others semen sample. It is essential that there is suitable privacy, time and environment for patients to do this. Donor records and coding of the specimens stored must be kept securely. The centers should audit their cryobanks annually. As per the ICMR guidelines, the semen bank shall not supply semen of one donor for more than 10 successful pregnancies. It will be the responsibility of the ART clinic or the patient, to inform the bank about a successful pregnancy. The bank shall keep a record

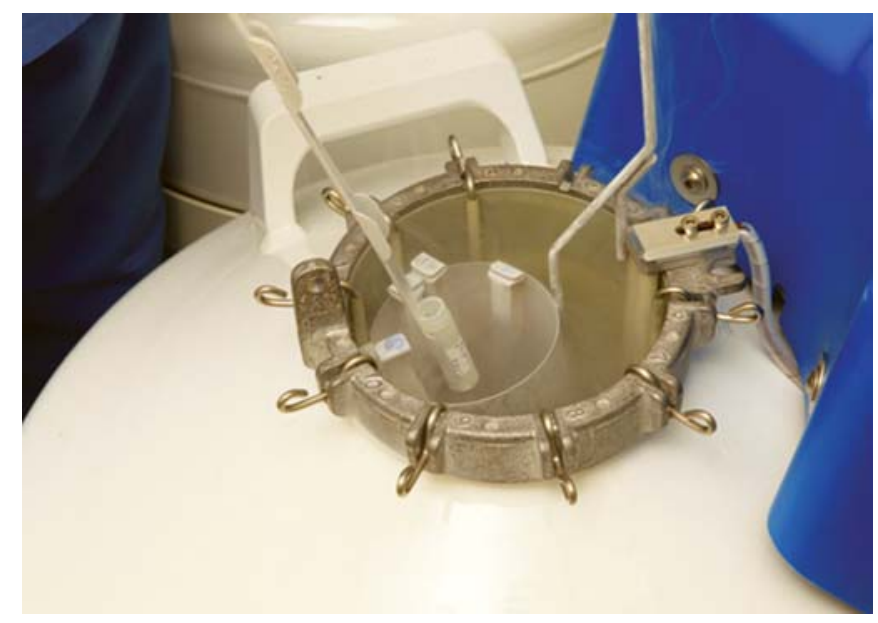

Fig. 3: Cryovial loaded on the aluminum cane is being placed in the cryocan

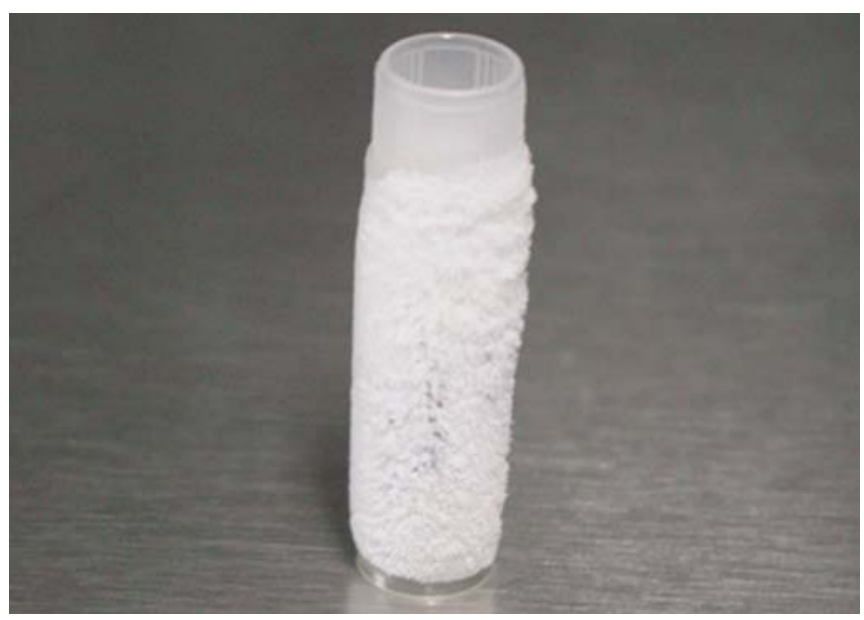

Fig. 4: Cryovial being thawed at the room temperature. Sweating on the vial can be appreciated 
of all semen received, stored and supplied, and details of the use of the semen of each donor. This record will be liable to be reviewed by the accreditation authority. A semen bank may store a semen preparation for exclusive use on the donor's wife or on any other woman designated by the donor. An appropriate charge may be levied by the bank for the storage. In the case of nonpayment of the charges when the donor is alive, the bank would have the right to destroy the semen sample or give it to a bonafide organization to be used only for research purposes. In the case of the death of the donor, the semen would become the property of the legal heir or the nominee of the donor at the time the donor gives the sample for storage to the bank. In the United Kingdom, the semen is not normally stored for longer than 10 years or beyond the age of 55 years for donors; generally it is not stored in France, for more than 5 years. Donors may express a wish to further limit the period of storage or the number of pregnancies that can be obtained from one donor. This is restricted to 10 children by the same donor. Confidentiality remains a primary consideration in most countries.

\section{DONOR SCREENING PRIOR TO SEMEN BANKING}

Fresh donor insemination is not recommended for the fear of transmission of common infective diseases. Donors should be tested for HIV 1 and 2, HTLV I and II antibodies, hepatitis B surface antigen, hepatitis B core antibody, hepatitis C, RPR, TP-PA, cytomegalovirus antibodies, chlamydia and gonorrhea. Some agents and diseases that can be transmitted by the seminal fluid include HIV, hepatitis B, hepatitis C and syphilis.

Table 7: Methods of semen freezing

\begin{tabular}{lll}
\hline Methods & Principles & Storage \\
\hline Vapor-phase cooling & $\begin{array}{l}\text { 1. The procedure is carried out manually } \\
\text { 2. LN2 is always vaporizing due to its low boiling point and } \\
\text { thus vapor phase that naturally exists around liquid } \\
\text { nitrogen tank is utilized for desired cooling }\end{array}$ & $\begin{array}{l}\text { Sample is stored either in the vapor } \\
\text { phase in the LN2 container or } \\
\text { dipped in the LN2 after gradual cooling }\end{array}$ \\
$\begin{array}{l}\text { 3. The cryovials/straws are placed at predetermined } \\
\text { heights above liquid phase for predetermined periods } \\
\text { so the desired cooling curve is attained }\end{array}$ & \\
$\begin{array}{l}\text { Programmable } \\
\text { freezing machine }\end{array}$ & $\begin{array}{l}\text { Not essential for human sperm cryopreservation probably } \\
\text { because freezing machine such automated device is not } \\
\text { needed for sperm freezing }\end{array}$ & Sample is stored in the liquid phase \\
& $\begin{array}{l}\text { 2. Sample is loaded in the straw or the vial } \\
\text { 3. These are then cooled using a programmable machine and } \\
\text { then dipped in liquid nitrogen }\end{array}$ & \\
\hline
\end{tabular}

Table 8: Sperm freezing step-by-step

\begin{tabular}{|c|c|c|}
\hline $\begin{array}{l}\text { Sperm cryopreservation } \\
\text { method }\end{array}$ & \multicolumn{2}{|c|}{$\begin{array}{l}\text { Sample preparation } \\
\text { 1. Ensure both the sample and sperm cryopreservation buffer (K-SISC) are at room temperature } \\
\text { 2. Mix two volumes of sperm cryopreservation buffer to } 1 \text { volume of the sample } \\
\text { 3. Leave mixture for } 10 \text { minutes at room temperature } \\
\text { 4. Label straws with relevant information } \\
\text { 5. Load the sample into a freezing straw or cryovial and seal according to manufacturer's instructions } \\
\text { Freezing } \\
\text { A controlled rate freezing system is recommended for freezing using liquid nitrogen vapor, however, } \\
\text { results could vary, such method should be validated by the individual laboratory }\end{array}$} \\
\hline \multirow[t]{2}{*}{ Freezing } & Straws & Cryovials \\
\hline & $\begin{array}{l}\text { Load straws into freezing machine and } \\
\text { initiate freeze program for straws } \\
\text { should have similar parameters to } \\
\text { the given below: } \\
\text { - Start temperature is } 20^{\circ} \mathrm{C} \\
\text { - Cooling rate of } 6^{\circ} \mathrm{C} / \mathrm{min} \text { until }-80^{\circ} \mathrm{C} \\
\text { - At }-80^{\circ} \mathrm{C} \text { plunge them } \\
\text { into liquid nitrogen }\end{array}$ & $\begin{array}{l}\text { Load cryovials into freezing machine and initiate freeze } \\
\text { program. The freeze program for cryovials should have } \\
\text { similar parameters to those given below: } \\
\text { - Start temperature is } 20^{\circ} \mathrm{C} \\
\text { - Cooling rate of }-0.5^{\circ} \mathrm{C} / \mathrm{min} \text { to }+5.0^{\circ} \mathrm{C} \\
\text { - At }+5.0^{\circ} \mathrm{C} \text { cool at a rate of }-1^{\circ} \mathrm{C} / \mathrm{min} \text { to }+4.0^{\circ} \mathrm{C} \\
\text { - At }+4.0^{\circ} \mathrm{C} \text { cool at rate of } 2^{\circ} \mathrm{C} / \mathrm{min} \text { to }+3.0^{\circ} \mathrm{C} \\
\text { - At }+3.0^{\circ} \mathrm{C} \text { cool at a rate of }-4^{\circ} \mathrm{C} / \mathrm{min} \text { to }+2.0^{\circ} \mathrm{C} \\
\text { - At }+1.0^{\circ} \mathrm{C} \text { cool at a rate of }-10^{\circ} \mathrm{C} / \mathrm{min} \text { to }-80.0^{\circ} \mathrm{C} \\
\text { - At }+80^{\circ} \mathrm{C} \text { hold for } 10 \text { minutes } \\
\text { - Plunge into liquid nitrogen }\end{array}$ \\
\hline Thawing & \multicolumn{2}{|c|}{$\begin{array}{l}\text { 1. Remove straws or cryovials from liquid nitrogen and place them at room temperature until thawing } \\
\text { is complete } \\
\text { 2. Open the straws or cryo-tube and remove the thawed semen } \\
\text { 3. Dilute the semen with gamete buffer }(1: 1) \text { to reduce the toxic effect of glycerol } \\
\text { 4. Quickly evaluate the survival of the sperm. Immediately prepare sperm by the density gradient } \\
\text { method using sperm gradient or the swim-up }\end{array}$} \\
\hline
\end{tabular}


Donors are screened for the infections at the time of presentation. As a donor may be in window period of an infection, it is necessary to repeat the examination for hepatitis $\mathrm{B}$ and HIV after an appropriate quarantine period of 180 days. If the history or physical examination indicates infection, the donor should be rejected and advised to seek appropriate medical advice. Donor should be thoroughly screened for common genetic and communicable diseases and those specific to their geographic location before their enrollment in the program.

\section{CROSS-INFECTION IN THE SEMEN BANKS}

There is a potential danger of cross-infection within the bank, thus the samples must be handled and stored with paramount care. Cryopreserved semen may be spilled in the cryocan, and the infectious organism (hepatitis B virus) may survive in the liquid nitrogen with the possibility of cross-infection of other stored samples. It is recommended that samples be stored in isolation cryocans till the quarantine period of $\mathrm{HIV}, \mathrm{HbsAg}$ and HCV. Use of CBS (CryoBioSystem, Paris, France) ionomeric straws which have been hermetically sealed offers protection against cross-infection. Men with malignancy often need to bank their semen at short notice as to preclude complete prefreeze infective screening. These men's semen could be reposited in a quarantine tank until the requisite screening had been completed. Client depositor/autologous who has the comfort of time, e.g. men considering a vasectomy, a cryobank must insist upon screening for infective pathogens as a safety precaution for the security of other men's semen stored in the same canister. When the samples are cryopreserved for patients who are known to carry an infective infection, e.g. HIV/HbsAg, these can be stored in separate 'contaminated' tanks. There must be a separate tank for each of recognized pathogenic organisms. In the United States and United Kingdom, guidelines have been published. The HEFA is moving towards a position whereby laboratories will be compelled to screen donors in this way. ${ }^{35}$

\section{SECURITY OF THE SEMEN BANK}

The straws or vials must be clearly labeled. Inventory control is of utmost importance. Every precaution must be made to ensure that each straw or vial can be linked to the sperm source, date of cryopreservation and specimen number, canister/cane or rack/cryocan number. The cryocans have a locking facility which must be utilized and limited staff allowed access to the keys. Lot of softwares are available in the industry for easy identification of the specimen. Some example of vial or straw identification mechanisms currently employed by sperm banks include: computerized or manual bar coding system, color coding with cryomarkers, vial caps or straw plugs or use of adhesive labels.

Secure cryopreservation of semen requires regular maintenance of the equipment and refilling of liquid nitrogen in the cryocans. Liquid nitrogen evaporates very quickly or the cans can leak thus causing loss of precious samples. The loss of stored semen from cancer or other patients, like those having spinal cord injuries and in whom semen has been retrieved with electroejaculation is not only difficult to quantify but also is of immense emotional value to the owner/couple. All the details and records must be stored confidentially and country specific guidelines adhered to when carrying out cryofreezing at the center. The following measures are considered customary by various accreditation authorities:

i. The levels of liquid nitrogen (LN2) in cryocans that are filled manually should be monitored on a regular basis, using a cryoscale.

ii. In large cryobiorepository, cans may be attached to automated cryo manifold with 'auto-fill' controller.

iii. Low-level and temperature sensors should be installed in all cryogenic storage tanks and connected to an alarm that will alert biologist to unwarranted problems.

\section{THE FUTURE OF SEMEN CRYOPRESERVATION}

Cryopreservation of human gametes expose them to numerous stresses, including mechanical, thermal and chemicophysiological, which can lead to compromised function of the gametes. We have come a long way since accidental discovery of glycerol as cryoprotectant for human sperms. The enigma of finding an ideal cryoprotectant would be the holy grail of the modern cryobiology. The applications of semen cryopreservation which had humble origin in veterinary practice now entails cryopreservation of stem cell derived male sperms, though in experimental stages using vitrification. The introduction of clinical intracytoplasmic sperm injection (ICSI) in 1992, at Brussels opened a new era in the field of assisted reproductive techniques, allowing couples with severe male factor infertility to hope for a child of their own genetic origin. Nearly 2 years later, it was established that pregnancy was possible by carrying out ICSI on sperms extracted by surgical sperm retrieval techniques. ${ }^{38}$ Nagy et al showed that comparable result in terms of pregnancy rates can be obtained by performing ICSI with ejaculated, epididymal or testicular spermatozoa, although fertilization rates were significantly higher with the ejaculated sperm. Epididymal spermatozoa can be retrieved either by microsurgery or by percutaneous needle puncture. These can be subsequently cryofreezed. ${ }^{36,37}$ The frequent indication for epididymal aspiration is obstructive azoospermia and thus it is not uncommon for relatively large quantities of sperm to be obtained and subsequently used for IVF or even intrauterine insemination (IUI). Surplus sperm may be frozen for future use. If a large numbers of epididymal spermatozoa are obtained, then density gradient centrifugation is an effective method for preparing those spermatozoa for subsequent use. Testicular specimens are contaminated invariably with large amounts of red blood cells and testicular tissues; additional steps are needed to isolate a clean preparation of spermatozoa. In order to free the seminiferous tubule-bound spermatozoa, it is necessary to use either enzymatic digestants (collagenase) or mechanical methods. For the latter, testicular tissues in supportive culture medium is macerated using glass cover slips until a fine slurry of dissociated tissues is produced, and the resulting suspension can then be processed for therapeutic use. 
Excess testicular spermatozoa obtained in this manner can be frozen for future use in order to avoid further surgeries. ${ }^{39}$ Testicular spermatozoa can also be obtained from a needle biopsy, although only a small amount of tissue is usually retrieved and the resulting sperm yield is proportionately low. Another method is cryopreservation of single human spermatozoa in empty human zona shell, which is established by Jacques Cohen. A hollow sphere remains when cellular material is removed from the zona. Because it can be seen and handled microscopically both before and after cyropreservation, it is an ideal capsule for freezing individual, and small groups of sperm cells. ${ }^{40}$ Recently vitrification has been applied to semen freezing. Recovery of sperms for IVF has been poor for severely oligospermia males in conventional semen freezing techniques. Thus the concept of cryoprotectant free vitrification of semen sample was mooted. Adequate number of sperms were recovered by ultrafast freezing of the prepared sample and then warming them to $37^{\circ} \mathrm{C}$ using copper loops as carrier device. ${ }^{41,42}$ Semen banking is going to encompass testicular tissue banking in greater number of patients in the years to come.

\section{EMERGING ROLE OF SEMEN BANKING IN ONCO-ART}

Malignancy is one of the common diseases with approximately $50 \%$ of men facing this diagnosis during the course of their lifetime. Till date, the focus of clinicians has been on timely diagnosis and appropriate treatment of the patients. With increasing favorable outcome, the focus is shifting to fertility preservation. ${ }^{43,44}$ This, in turn, has provided many patients with the opportunity to live complete lives, allowing them to reflect on life subsequent to treatment. Fertility issues, such as posttreatment marriage and parenthood, are considered as important by many parents and young patients. At the time of cancer diagnosis, patients and clinicians alike are often weighed down by the large number of urgent tests and procedures that must be carried out in a timely manner. In the present scenario proactivity is desired from the oncology and the assisted reproductive team alike. There is no specific consideration for semen banking in such cases except the time factor and stress they are facing. Sample may be collected as in normal healthy males. We encounter difficulty in young boys/teenagers who are brought by the parents for semen banking. This is a psychologically traumatizing scenario for the parents, child and the clinicians, such delicate situations may require psychological counseling. ${ }^{45}$ Another problem we face is in young males who are not permitted to masturbate as per the religious guidelines. Such males are advised testicular tissue extraction and banking. Similar protocol is being followed for young cancer patients who do not masturbate. It is recommended to bank multiple vials/straws of the samples as the recovery may not be very good especially in postchemotherapy and/or radiotherapy patients. Intracytoplasmic sperm injection is the recommended treatment for such patients. Majority of the cancer patients do have sufficient time when they visit us. We should start the procedure on the day of referral itself, if possible. Minimum six straws should be frozen from 2 to 3 samples collected 24 hours apart. The patient and the parents should be counseled about the subsequent modality of treatment. The chances of offering ICSI should be discussed at length. Semen banking is commonly carried out in patients with testicular cancers, Hodgkin's disease and leukemias. ${ }^{46}$

\section{CONCLUSION}

Sperm banking has become a widely accepted mode of infertility treatment, and in recent times mooted as having new role as fertility insurance. Once looked upon with improbability, this practice has established to be a successful technique of keeping the anticipation of a family alive for countless families. The motives for storage are as diverse as humans themselves. So far, no limit has been established for how long human semen can be frozen when maintained and stored in appropriate liquid nitrogen storage. Scientific literature shows conclusively that sperm motility, viability and morphology are not affected by proper long-term cryopreservation. Cryo-thaw semen pregnancies have been reported after 2 to 3 decades of semen banking. ${ }^{47,48}$ Appropriate screening should be carried out before semen banking as per available guidelines. Currently acceptable guidelines include those by the British Andrology Society ${ }^{49}$ and the Practice Committee of the American Society for reproductive medicine. ${ }^{50}$

\section{REFERENCES}

1. Parkes AS. Preservation of human spermatozoa at low temperatures. Brit MJ 1945;2:212-13.

2. Sherman JK, Buge RG. Observations on preservation of human spermatozoa at low temperatures. Proc Soc Exp Biol Med 1953;82:686-88.

3. Hammerstedt RH, Graham JK, Nolan JP. Cryopreservation of mammalian sperm. What we ask them to survive? J Androl 1990;11:73-88.

4. Spallanzani L, Opuscoli di Fisca, Amimale, e Vegetgabile, Opuscolo II. Osservazioni, e Speriencze inotrno ai Vermicelli Spermatici dell'Uomo e degli Amimali. Modena 1776.

5. Montegazza J. Fisologia sullo sperma umano. Rendic reale Instit Lomb 1866;3:183-85.

6. Shettels LB. The respiration of human spermatozoa and their response to various gases and low temperatures. Am J Physiol 1940;128:404-15.

7. Hoagland H, Pincus G. Revival of mammalian sperm after immersion in liquid nitrogen. J Gen Physiol 1942;25:337-44.

8. Polge C, Smith AU, Parkes AS. Revival of spermatozoa after vitrification and dehydration at low temperatures. Nature 1949;164:666-70.

9. Sherman JK. Research on frozen human semen. Past, present, and future. Fertil Steril 1964;485-99.

10. Meryman HT. Mechanics of freezing in living cell and tissues. Science 1956;124:515-21.

11. Quinn PH. Principles of membrane stability and phase behaviour under extreme conditions. J Bioenerg Biomemb 1989;21:3-19.

12. Carruthers A, MElchior DL. Role of bilayer lipids in governing membrane transport processes. In: Aloia RC, Curtin, CC, Gordon LM (Eds). Lipid domains and the relationship to membrane function. New York, Liss 1988b;201-25. 
13. Smith AU, Ploge C, Smiles JIX. Microscopic observation of living cell during freezing and thawing. J Roy MIcr Soc 1951;71:186-95.

14. Drobnis EZ, Crowe LM, Berger T, Anchordoguy TJ, Overstreet JW, Crowe JH. Cold shock damage is due to lipid phase transitions in cell membrances: A demonstration using sperm as a model. $\mathrm{J}$ Exp Zool 1993;265:432-37.

15. Holt WV, North RD. Effects of temperature and restoration of osmotic equilibrium during thawing on the induction of plasma membrane damage in cryopreserved ram spermatozoa. Bio Reprod 1992;46:1086-94.

16. Farrant J. Mechanism of cell damage during freezing and thawing and its prevention. Nature 1965;205:1284-87.

17. Shapiro SS. Strategies to improve efficiency of therapeutic donor insemination. In: Diamond MP, DeCherney AH (Eds). Infertility and Reproductive Medicine Clinics in North America. Male infertility, Philadelphia: WB Saunders 1992;469-85.

18. Bordson BL, Ricci E, Dicky RP, Dunway H,Taylor SN, Curole DW. Comparison of fecundability with fresh and frozen semen in therapeutic donor insemation. Fertile Steril 1986:466-69.

19. Barthelemy D, Royere D, Hammahah S, Lebos C, Tharanne MJ, Lansac J. Ultrastructural changes in membrane and acrosome of human sperm during cryopreservation. Arch Andor 1990;25:29-40.

20. Lasso JL, Noiles EE, Alvaraz JG, S Dtorey BT. Mechanism of superoxide dismutase loss from human sperm cell during cryopreservation. J Andor 1994;15:255-65.

21. Van den Berg L, Soliman FS. Composition and $\mathrm{pH}$ changes during freezing of solutions containing calcium and magnesium phosphate. Cryobiology 1969;6:10-14.

22. Mortimer D. Semen cryopreservation. In: Practical Laboratory Andrology. Oxford: Oxford University Press 1994.

23. Hammit DG, Walker DL, Willamson RA. Concentration of glycerol required for optimal survival and in vitro fertilization capacity of frozen sperm is dependent on cryoperservation medium. Fertil Steril 1988;49:680-87.

24. Zimmerman SJ, Maude MB, Modldawer M. Freezing and storage of human semen in 50 healthy medical students. A comparative study of glycerol and dimethyl sulfoxide as a preservative. Fertil Steril 1964;15:505-10.

25. Mahadevan M, Trounson A. Effects of cryopreservation media and dilution methods on the preservation of human spermatozoa. Andrologia 1983;15:355-66.

26. Prins GS, Weidel L. A comparative study of buffer systems as cryoprotectants for human spermatozoa. Fertil Steril 1986;46: 147-49.

27. Ramirez, JP, Carreras A, Mendoza C. Sperm plasma membrane integrity in fertile and infertile men. Andrologia 1992;24: $141-44$.

28. Jeyendran RS, Van der Ven HH, Kennedy W, Perez-Pelaez M, Zanelveld LJD. Comparison of glycerol and a zwitterions buffer system as cryoprotective media for human spermatozoa: Effect on motility, penetration of zona-free hamster oocytes, and acrosin/proacrosin. J Andorl 1984;5-7.

29. Richardson DW, Sadlier RM. The toxicity of various nonelectrolytes to human spermatozoa and their protective effects during freezing. J Reprod Fertil 1967;14:439-44.

30. Mazur P. Freezing of living cells: Mechanisms and implications. Am J Physiol 1974;247:C125-42.

31. Tyler JPP, Kime L, Cooke S, Driscoll GL. Temperature change in cryo-containers during short exposure to ambient temperatures. Hum Reprod 1996;11:1510-12.
32. Graham EF, Crabo BG. Some methods of freezing and evaluating human spermatozoa. Proc Natl Acad Sci 1978;4: 274-304.

33. Bunge RG, Keetel WC, Sherman JL. Fertilization capacity of frozen human spermatozoa. Nature 1953;172:767-68.

34. Mclaughlin EA, Ford WCL, Hull MGR. The contribution of the toxicity of a glycerol-egg yolk-citrate cryopreservative to the decline in human sperm motility during cryopreservation. J Repord Fertil 1992;95:749-54.

35. Human Fertilization and Embryology Act 1990. Schedule 3 para 2(2)(b). HMSO, London.

36. Oates RD, Lobel SM, Harris D, et al. Efficacy of intracytoplasmic sperm injection using intentionally cryopreserved epididymal sperm. Hum Reprod 1996;11:133-38.

37. Testicular sperm extraction and cryopreservation in patients with non-obstructive azoospermia prior to ovarian stimulation for ICSI. Taha Abd Elnaser, MD, Hamsa Rashwan, Middle East Fertility Society Journal 2004;9(2):128-35.

38. Oates RD, Mulhall J, Burges C, Cunniingham D, Carson R. Fertilization and pregnancy using intentionally cryopreserved testicular tissue as the sperm source for intracytoplasmic sperm injection in 10 men with non-obstructive azoospermia. Hum Reprod 1997;12:734-39.

39. Gil-Salom M, Romero J, Minguez Y, et al. Pregnancies after intracytoplasmic sperm injection with cryopreserved testicular tissue. Hum Reprod 1996;11:1309-13.

40. Cohen J, Garrisi GJ, Congedo-Ferrara TA, Kieck KA, Schimmel TW, Scott RT. Cryopreservation of single human spermatozoa. Human Reproduction 1997;12:994-1001.

41. Isachenko V, Isachenko E, Katkov II, Montag M, Dessole S, Nawroth F, Van Der Ven H. Cryoprotectant-free cryopreservation of human spermatozoa by vitrification and freezing in vapor: Effect on motility, DNA integrity, and fertilization ability. Biol Reprod Oct 2004;71(4):1167-73.

42. Isachenko E, Isachenko V, Katkov II, et al. DNA integrity and motility of human spermatozoa after standard slow freezing versus cryoprotectant-free vitrification. Hum Reprod 2004;9(4): 932-39.

43. Tomlinson MJ, Pacey AA. Practical aspects of sperm banking for cancer patients. Hum Fertil 2003;6(3):100-05.

44. Wallace WH, Anderson RA, Irvine DS. Fertility preservation for young patients with cancer: Who is at risk and what can be offered? Lancet Oncol 2005;6(4):209-18.

45. Saito K, Suzuki K, Iwasaki A, Yumura Y, Kubota Y. Sperm cryopreservation before cancer chemotherapy helps in the emotional battle against cancer. Cancer 2005;104(3):521-24.

46. Schmidt KL, Carlsen E, Andersen AN. Fertility treatment in male cancer survivors. Int J Androl 2007;30(4):413-19.

47. Horne G, Atkinson AD, Pease EH, et al. Live birth with sperm cryopreserved for 21 years prior to cancer treatment: Case report. Hum Reprod 2004;19(6):1448-49.

48. Feldschuh J, Brassel J, Durso N, Levine A. Textbook of Assisted Reproductive Technologies. Successful sperm storage for 28 years. Fertil Steril 2005;84(4):1017.

49. British Andrology Society. British Andrology Society guidelines for the screening of semen donors for donor insemination 1999. Hum Reprod 1999;14(7):1823-26.

50. Guidelines for gamete and embryo donation. The American Society for Reproductive Medicine. Fertil Steril 1998; 70(4 Suppl 3):1S-13S. 